EESTI NSV TEADUSTE AKADEEMIA TOIMETISED. 19. KÖIDE

KEEMIA * GEOLOOGIA. 1970, Nr. 2

ИЗВЕСТИЯ АКАДЕМИИ НАУК ЭСТОНСКОН ССР. ТОМ 19

ХИМИЯ * ГЕОЛОГИЯ. 1970 , № 2

ВИИВЕ ВИИРРА, Э. КИВИМЯГИ, А. ЛООГ

\title{
О ЛИТОЛОГИИ И ВОЗРАСТЕ ВАРАНГУСКОЙ ПАЧКИ (ТРЕМАДОК СЕВЕРНОИ ЭСТОНИИ)
}

В Северной Эстонии между диктионемовыми аргиллитами пакерортского горизонта (тремадокский ярус) и глауконитовыми песчаниками латорпского горизонта (аренигский ярус) залегают серые сланцеватые глины, впервые упомянутые Х. Беккером (Bekker, 1923). В 1946 году А. Луха (Luha, 1946) по соотношению мощностей диктионемового аргиллита и сланцеватых глин сделал вывод, что они замещают друг друга в разрезе. Р. Мянниль (1958), основываясь на исследованиях К. Мююрисеппа, выделил сланцеватые глины в самостоятельную варангускую пачку и рассматривал ее в составе лэзтсеского горизонта. $\mathrm{K}$ пакерортскому горизонту отнес сланцеватые глины K. Стумбур (1962), который более подробно изучал литологию и фауну варангуской пачки, а также А. Лоог (Loog, 1964), А. Лоог и Э. Қивимяги (1968) и др.

Существование такого неоднозначного решения вопроса о возрасте варангуской пачки и побудило авторов к более детальному изучению литологии и биостратиграфии этих сланцевых глин. Літтологические исследования проводили А. Лоог и Э. Кивимяги, конодонты изучались В. Вийра.

Варангуская пачка распространяется в Северной Эстонии в виде субширотной дугообразной полосы шириной 20-40км (рис. 1). Северная граница распространения пачки на западе проходит по линии глинта, где сланцеватые глины обнажаются в нескольких местах (Гакерорт, Лээтсе, Кейла-Иоа). Далее на восток северная граница проходит южнее глинта и только у Таллина (обнажение Сухкрумяги) и на востоке, в районе Тоолсе - Азери (обнажения Карула, Варангу, Пада, Кунда, Азери и Пуртсе), снова находится на линии глинта. Южная дугообразная граница распространения сланцеватых глин проходит от Пальдиски до Пуртсе. При этом интересно, что южная граница распространения подстилающих диктионемовых аргиллитов и вышележащих глауконитовых песков проходит значительно южнее. Самые большие мощности сланцеватых глин встречаются по данным бурения в восточной части (у Тоолсе до 3,3 м), на юго-запад мощность пачки постепенно уменьшается и в западной части обычно не превышает 0,5 м.

Стратотипом варангуской пачки является обнажение на левом берегу реки Селья у села Варангу, где можно проследить следующую последовательность слоев пачки (сверху вниз):

1) 0,25 м пелит, алевритистый, светло-серый, тонко-слоистый, сланцеватый. В пелитовой основной массе встречаются неопределенной формы гнезда глауконитового алеврита (содержание алевритового материала увеличиваєтся к подошве слоя). Поверх- 


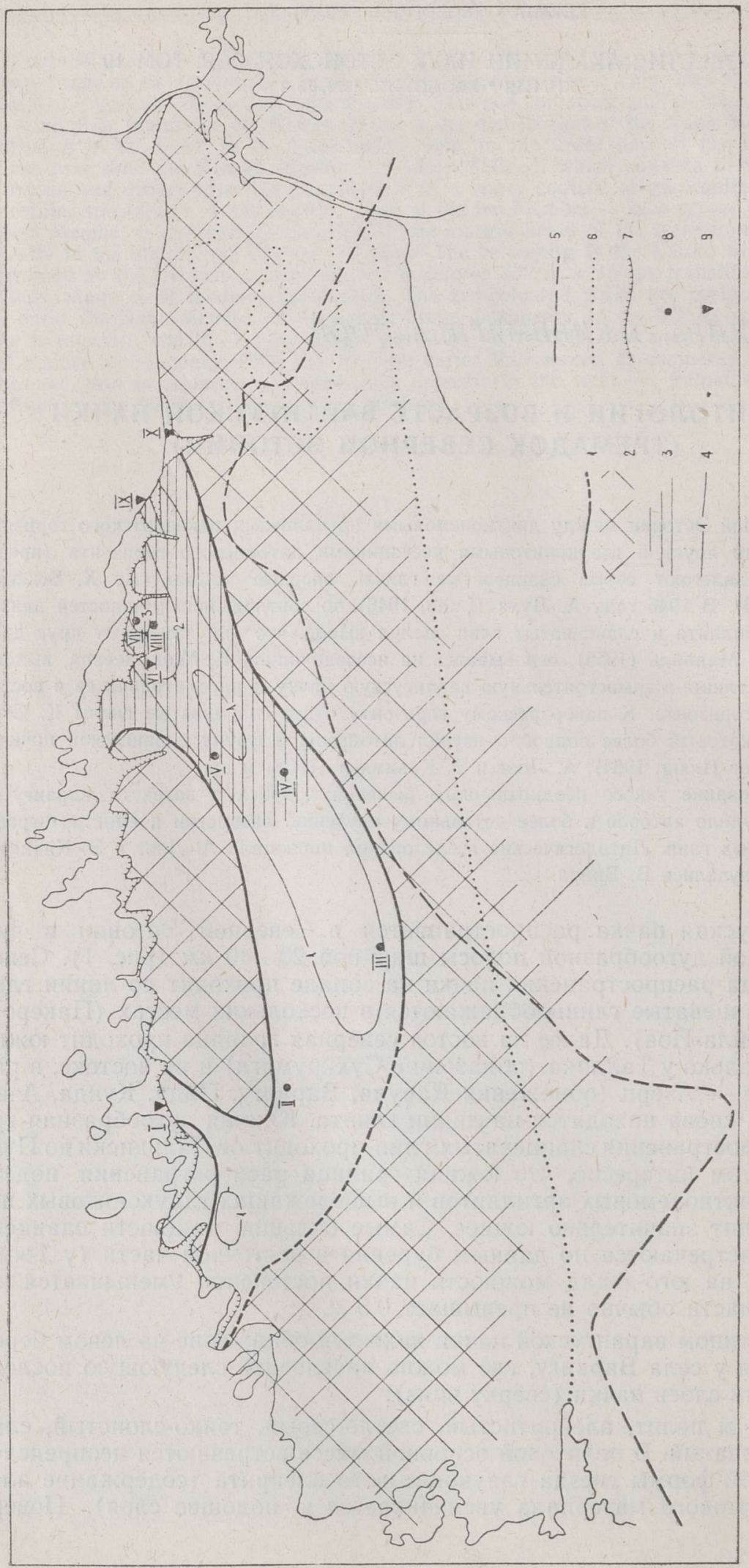

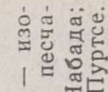

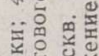

ज्ञ

크음

要

홀

政

동

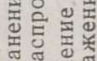

ํㅜㅇ

영명

跣

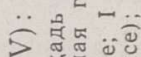

妾范部

ㄱ1 1 쭈ㅇㅝㅛ

56

获苛垔

줌분

क

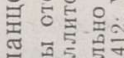

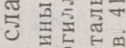

또농 함

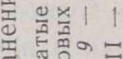

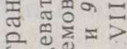

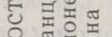

늘 5 롤

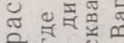

(5)

정

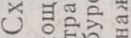

-

ป 1 定

…당

这采前

즘른 갤

है

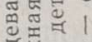

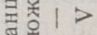

సुํ, $\infty$

近以 娄

可喓

㻤

을?

एँ

푤

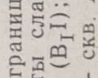

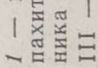


ность слоя размыта; есть много разнонаправленных ходов илоедов. Ходы заполнены глауконитовым песком, в котсром встречаются скопления кристаллов пирита. В вышележащих глауконитовых песках встречаются и окатанные гальки глин, поверхность которых импрегнирована окислами и гидроокислами железа.

2) 0,30 $⿻$ миктит, глауконито-кварцевый, песчано-алеврито-пелнтовый, зеленовато-серый. В нем встречаются гнезда и невыдержанные прослои (мощностью до 5 см) более светлого пелита и местами выклинивающиеся прослон темно-коричневого аргнллита.

3) 0,60 $м$ песчаник, глауконито-кварцевый, пелитисто-алевритовый, зеленовато-серый. В песчанике много невыдержанных прослоев серой глины. Встречаются отдельные плоские конкреции пирита (диаметром до 5 см

4) 0,25 м пелит, песчанисто-алевритовый, серый, сланцеватый, со многими выклинквающимися линзами глауконито-кварцевого алеврита (моцностью до 3 мм). Слонстость горизонтальная, но слабо выраженная.

5) 0,30 м песчаник, глауконито-кварцевый, пелитисто-алевритовый, зеленовато-серый.

6) 0,50 $\boldsymbol{x}$ алевролит, глауконито-кварцевый, пелитисто-песчанистый, серый, горизонтальнослоистый. Слоистость выражается расположением зерен глауконита на плоскостях напластования. Встречаются гнезда и линзы глауконитового песка.

7) 0,15 м миктит, глауконито-кварцевый, песчанисто-алевритистый, зеленовато-серый, со многими кристаллами пирита.

8) 0,25 пелит, песчанистоалеврнтовын̆, светлосерый, сланцеватый. Местами встречаются линзы глауконитовых зерен песчано-алевритовой размерности. Ннжняя граннца слоя резкая -- на сравнительно ровной поверхности подстилающих диктионемовых аргиллитов местами залегают линзы серого мелкозернистого песка, в котором встречаются обломкн створок брахиопод и лис. точки слюды.

Нижняя граннца варангу-

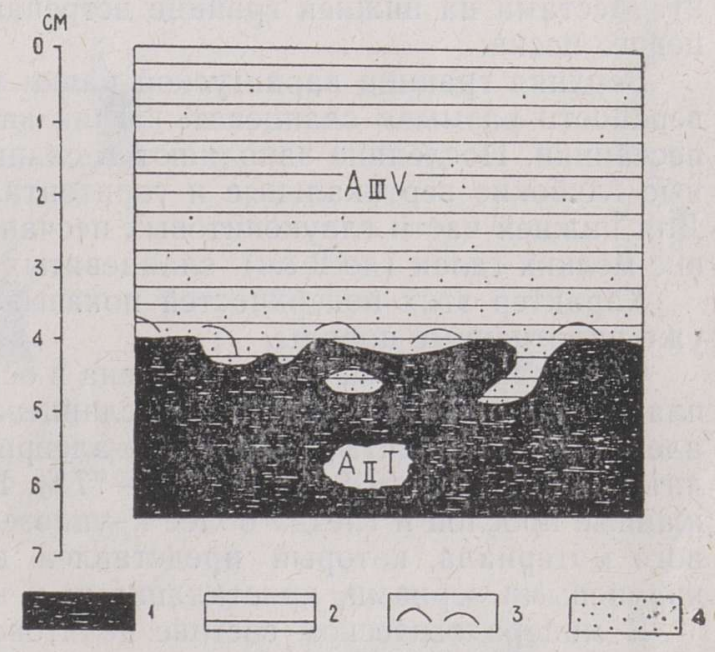

Рис. 2. Поверхность перерыва на границе диктионемовых аргиллитов и сланцеватых глин (скв. 420):

1 - диктионемовый аргиллит; 2 - сланцеватая глина; 3 - обломки створок беззамковых брахнопод; 4 кварц, алеврито-песчаной размерности. ской пачки литологически везде резкая и представлена по верхностью размыва. Поверхность подстилающих темно-коричневых аргиллитов в общем ровная с мелкими углублениями, местами имеются также вертикальные и наклонные ходы илоедов, заполненные глиной варангуской пачки (см. Стумбур, 1962). Последняя содержит 


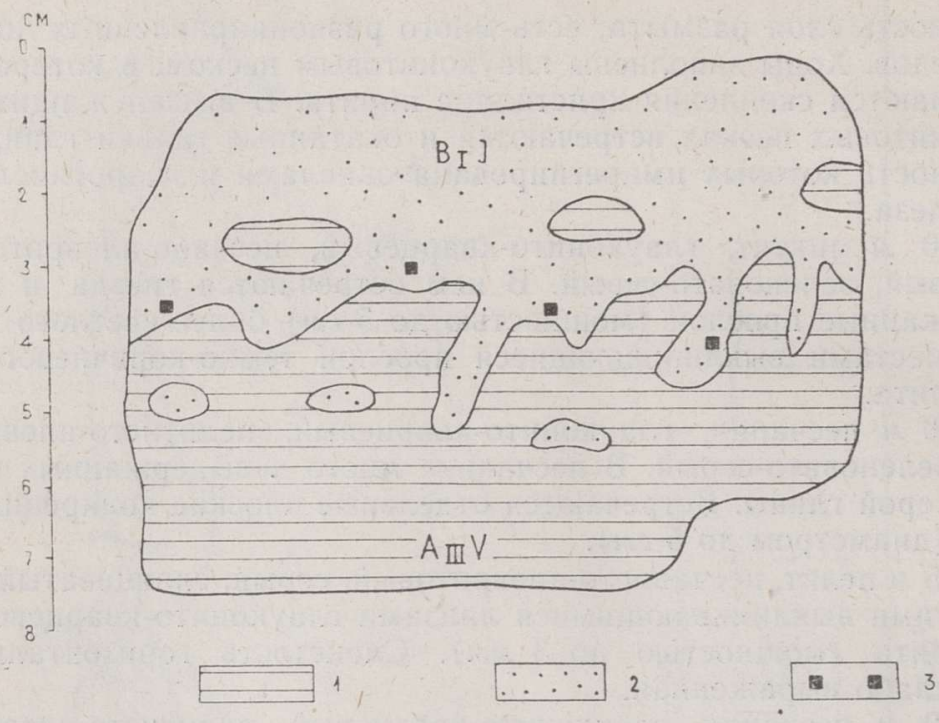

Рис. 3. Поверхность перерыва на границе сланцеватых глин и глауконитовых песчаников (обнажение Варангу):

1 - сланцеватая глина; 2 - глауконитовый песчаник; 3 - пирнт.

в большом количестве алевритовые частицы и песчаные зерна, а местами обломки беззамковых брахиопод и кристаллов пирита (рис. 2). Местами на нижней границе встречаются маломощные линзы кварцевого песка.

Верхняя граница варангуской пачки также резкая. На неровной поверхности размыва сланцеватых глин залегают зеленые глауконитовые песчаники. Последние заполняют в сланцеватых глинах и многочисленные глубокие вертикальные и горизонтальные ходы илоедов (рис. 3). Д.тя нижней части глауконитовых песчаников характерно еще присутствке мелких галек (до 2 см) сланцеватых глин и кристаллов пирита.

Характер этих поверхностей показывает, что размыву подвергались уже уплотненные породы.

Сама варангуская пачка сложена в основном плотными сухими малопластичными зеленовато-серыми сланцеватыми глинами (алевритовые и алевритистые пелиты, песчанисто-алевритовые пелиты), в которых пелитовый материал составляет $70-77 \%$. В глинах встречаются невыдержанные прослои и гнезда более крупнозернистого песчаного и алевритового материала, который представлен в основном глауконитовыми и кварцевыми зернами, кристалликами и конкрециями пирита.

В минералогическом составе пелитовой фракции пород варангуской пачки по данным рентгеноструктурного анализа, выполненного К. Ј'тсалом, преобладают гидрослюды $(85-95 \%)$, в небольшом количестве присутствует хлорит $(5-15 \%)$. В легкой фракции частиц крупно-алевритовой размерности $(0,05-0,1$ мм $)$ по нашим данным встречаются кварц $(35-65 \%)$, глауконит $(20-45 \%)$, полевые шпаты $(6-20 \%)$ и листочки слюды. Кроме названных минералов в легкой фракции встречаются еще обломки створок беззамковых брахиопод й диктионемового аргиллита. Содержание минералов тяжелой фракции обычно мало - не сколько десятых долей процента, и только при наличии большого количества аутигенных минералов оно может достигать нескольких процентов (до. $5 \%$ ). В тяжелой фракции крупноалевритовой размерности пре- 


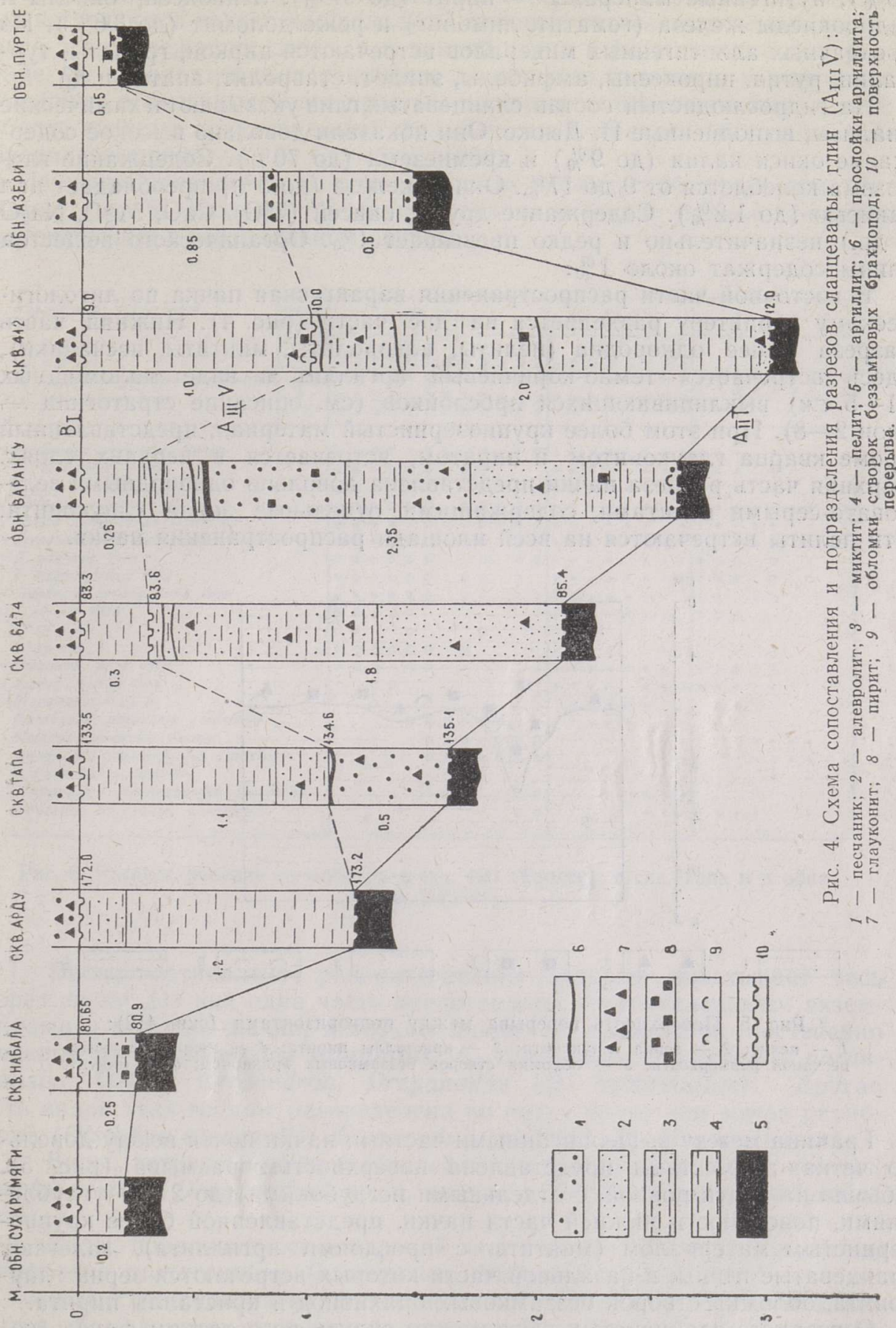


обладающими являются рудные минералы (ильменит, магнетит - до $26 \%$ ), аутигенные минералы - пирит (до $97 \%$ ), лейкоксен, окислы и гидроокислы железа (гематит, лимонит) и реже доломит (до 3,6\%). Из прозрачных аллотигенных минералов встречаются циркон, гранаты, турмалин, рутил, пироксены, амфиболы, эпидот, ставролит, апатит и др.

На гидрослюдистый состав сланцеватых глин указывают и химические анализы, выполненные И. Лыоке. Они показали довольно высокое содержание окиси калия (до $9 \%$ ) и кремнезема (до 70\%). Содержание глинозема колеблется от 9 до $17 \%$. Окись железа (до $5 \%$ ) преобладает над закисью (до 1,2\%). Содержание других окисей $\left(\mathrm{TiO}_{2}, \mathrm{CaO}, \mathrm{MgO}, \mathrm{Na}_{2} \mathrm{O}\right.$ и др.) незначительно и редко превышает $1 \%$. Органического вещества глины содержат около $1 \%$.

В восточной части распространения варангуская пачка по литологическому характеру разделяется на две части (рис. 4). Нижняя часть разреза менее однородна (пелиты, алевролиты, миктиты, песчаники), здесь встречается темно-коричневый аргиллит в виде маломощных $(1-5$ см) выклинивающихся прослойков (см. описание стратотипа слои 2-8). При этом более крупнозернистый материал, представленный кроме кварца глауконитом и пиритом, встречается в верхних слоях. Верхняя часть разреза пачки представлена довольно однородными зеленовато-серыми пелитами, содержащими отдельные зерна глауконита. Эти пелиты встречаются на всей площади распространения пачки.

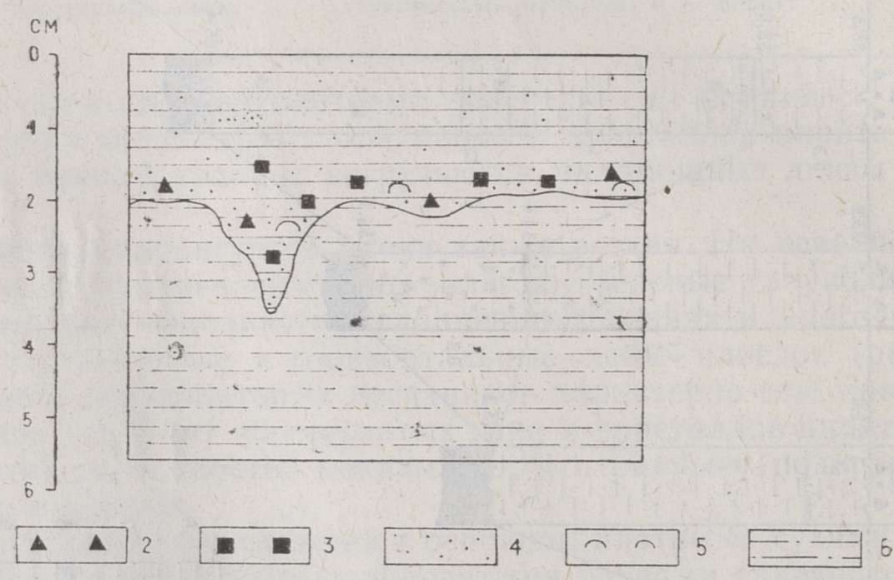

( Рис. 5. Псверхность перерыва между подгоризонтами (скв. 412):

1 - пелит; 2 - зерна глауконнта; 3 - кристаллы пирита: 4 - кварц, алевритопесчаной размерности; 5 - обломки створок беззамковых брахиопод; 6 - миктит.

Граница между вышеописанными частями пачки почти всюду довольно четкая и местами представлена поверхностью размыва (рис. 5). Обычно на почти ровной, с отдельными неглубокими (до 2 см) углублениями, поверхности нижней части пачки, представленной более крупнозернистым материалом (миктиты с прослоями аргиллита), залегают сланцеватые глины, в базальной части которых встречаются зерна глауконита, обломки створок беззамковых брахиопод и кристаллы пирита.

О возрасте сланцеватых глин можно судить по остаткам фауны, которые представлены в основном конодонтами. Встречаются также беззамковые брахиоподы, но их створки раздроблены и поэтому трудно определимы. В кровле пачки наблюдаются следы жизнедеятельности илоедов («Siphonia» cylindrica Eichw.). 
Конодонты варангуской пачки многочисленны и представлены в основном разнообразными простыми конусовидными формами. Из сложных встречаются только кордюлодусы, которые составляют основу комплекса в нижележащих слоях, а в данной пачке имеют подчиненное значение. От конодонтов вышележащего лээтсеского горизонта варангуские конодонты отличаются более простым характером боковых поверхностей и более низкими конусовидными формами; на последнее обстоятельствообратил внимание уже К. Стумбур (1962).

Изучение конодонтов по пяти разрезам варангуской пачки (см., например, рис. 6) выявило три группы видов, имеющие разный характерраспределения в вертикальном разрезе:

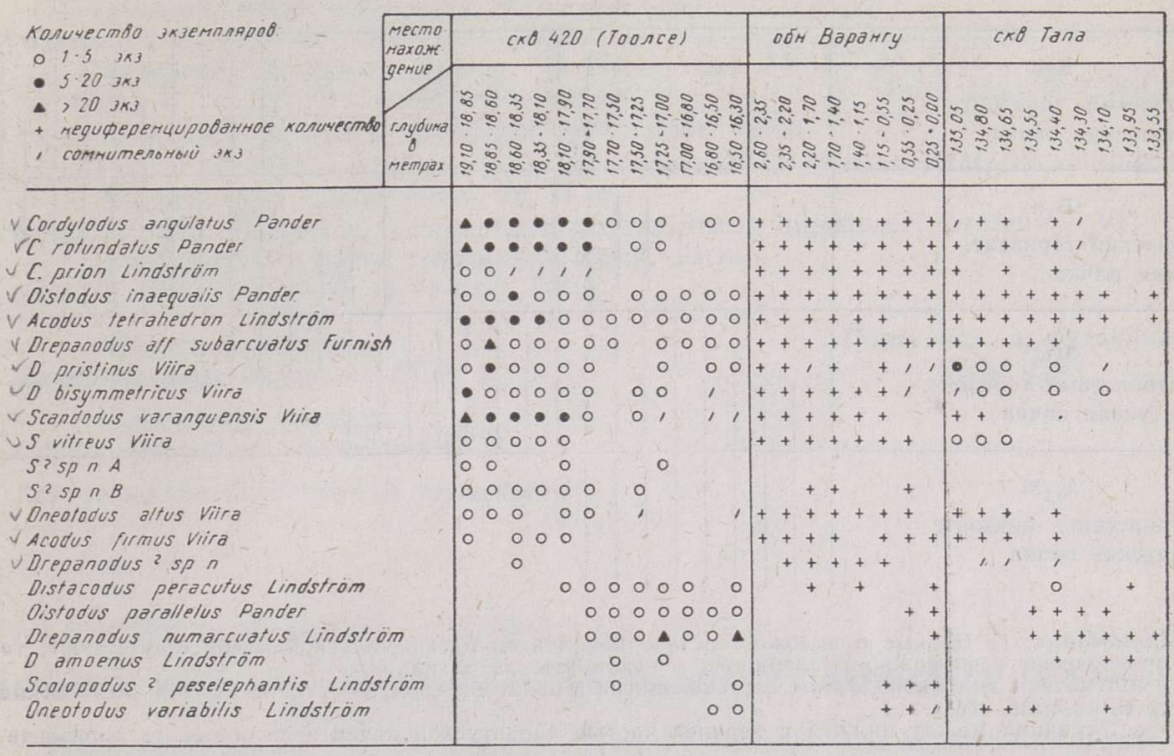

Рис. 6. Распространение конодонтов в скв. 420 (Тоолсе), в скв. Тапа и в обнажении Варангу.

1. Виды, вертикальное распросгранение которых охватывает весьразрез пачки. Из них одна часть представлена многочисленными экземплярами в подошве пачки, к верхам пачки их количество постепенно уменьшается (Cordylodus angulatus, C. rotundatus, Scandodus varan-guensis, Acodus tetrahedron, Drepanodus aff. subarcuatus). Другая часть видов этой группы распределена по пачке более или менее равномерно (Oistodus inaequalis, Drepanodus pristinus, D. bisymmetricus).

2. Виды, встречающиеся в нижней части пачки (Scandodus vitreus, Oneotodus altus, Drepanodus ? sp. п. и отчасти Acodus firmus, Cordylodus prion).

3. Виды, появляющиеся в верхней части пачки (Oistodus parallelus, Drepanodus numarcuatus, D. amoenus, Distacodus peracutus).

Комплекс конодонтов ва́рангуской пачки сходен с комплексом конодонтов тремадокских отложений скважин Блидене и Стури Западной Латвии. (см. Мянниль, 1963): Более того, последующее, более углубленное изучение конодонтов указанных отложений показало, что там встречаются также все те новые виды, которые обнаружены. в варангуской пачке Эстонии. 
Распространение видов конодонтов в пограничных слоях тремадока и аренига Эстонии

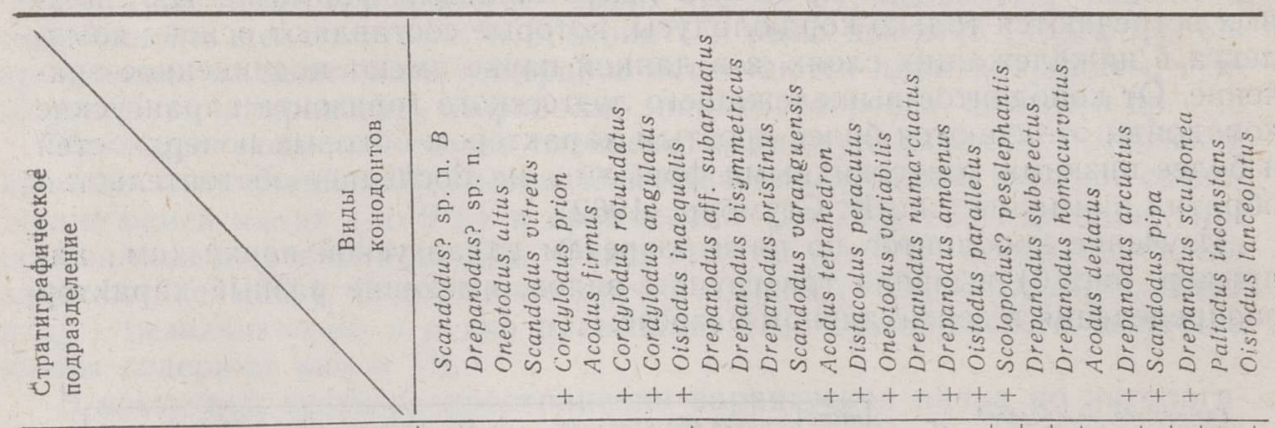

$\mathrm{B}_{\mathrm{I}} \mathrm{b}$

Латорпский горизонт, мяэкюлаская пачка

\section{$\mathrm{B}_{\mathrm{I}^{\mathrm{a}}}$}

Латорпский горизонт, 'нруская пачка

$$
\mathrm{A}_{\text {III }} \mathrm{V}
$$

Цератопигевый горизонт, варангуская пачка

$$
\mathrm{A}_{\mathrm{II}} \mathrm{M}
$$

Пакерортский горизонт,

маардуская пачка

Примечания: 1) Данные о видовом составе конодонтов в тюрисалуской пачке отсутствуют, так как практически невозможно препарировать конодонты из аргиллита.

2) + отмечены виды консдонтов, встречающнеся в цератопигевом известняке Швеции по М. Линдстрему (Lindström, 1955).

3) ... граница между нижней и верхней частью варангуской пачки цератопигевого горизонта.

M. Линдстрем (Lindström, 1955) указал следующие характерные конодонты для цератопигевых слоев Швеции: Acodus tetrahedron, Cordylodus angulatus, C. rotundatus. Эти виды распространены также и в варангуской пачке, особенно в нижней части ее. При этом вертикальное распространение двух последних видов более широкое. В цератопигевых слоях Швеции кроме вышеназванных встречается еще 15 видов, из которых в варангуской пачке обнаружены Cordylodus prion (в нижней части), Drepanodus numarcuatus, D. amoenus, Distacodus peracutus, Oistodus parallelus, Scolopodus? peselephantis (в верхней части) и Oistodus inaequalis, Oneotodus variabilis. Три первых из перечисленных видов установлены в Швеции только в цератопигевых слоях.

Из сравнения конодонтов варангуской пачки с конодонтами вышележащих глауконитовых песчаников ируской пачки латорпского горизонта (аренигский ярус) выясняется, что несмотря на некоторые общие виды (см. таблицу) в глауконитовых песчаниках происходит обновление конодонтов. Появляются новые виды: Acodus deltatus, A. erectus, Acontiodus latus, Scandodus piра и др. (Вийра, 1966).

Из всего изложенного выше явствует, что видовой состав конодонтов в цератопигевых слоях Швеции, характерен и для варангуской пачки Эстснии (см. таблицу). Последнее позволяет нам предполагать, что варангуская пачка Эстонии соответствует либо всему цератопигевому гори- 
зонту, либо части его. На основе распространения видов конодонтов в вертикальном разрезе варангуской пачки (цератопигевого горизонта) можно вы,делить две части (два подгоризонта?), которые совпадают с выделенными по литологическим признакам подразделениями разреза.

\section{Л H T E P A T У P A}

В и йр а В. 1966. Распространение конодонтов в нижнеордовикских отложениях разреза Сухкрумяги (г. Таллин). Изв. АН ЭССР, Сер. физ.-матем. и техн. наук, 15. № 1 .

Л оог А., К и в и яг и $Э$. 1968. Литостратиграфия пакерортского горизонта в Эстонии. Изв. АН ЭССР, Хим. Геол., № 4.

Мянни и л Р. М. 1958. Ордовикская система. В кн.: Обзор стратиграфии палеозойских и четвертичных отложений Әстонской ССР. Таллин.

М янни ль P. M. 1963. Биостратиграфическое обоснование расчленения ордовикских отложений Западной Латвии. Тр. Ин-та геол. АН ЭССР, ХІІІ.

С т у м б у р К. А. 1962. О стратиграфии варангуской пачки. Тр. Ин-та геол. АН ЭССР, Х. Bekker, H. 1923. Ajaloolise geoloogia õpperaamat. Tartu.

Lindström M. 1955. Conodonts from the lowermost Ordovician strata of south-central Sweden. Geol. Fören. Förh., 76, H. 4.

Loog A. 1964. Pakerordi lademe litostratigraafilisest liigestusest avamusel. VII Eesti Loodusuurijate päeva ettekannete teesid. Tartu.

I u h a A. 1946. Eesti NSV maavarad. Tartu.

Ннститут геологии

Академии наук Эстонской ССР

Управление геологии

Совета Министров Эстонской ССР

тартуский государственный университет
Поступила в редакщию 28/XI 1969

\section{VIIVE VIIRA, E. KIVIMÄGI, A. LOOG}

\section{VARANGU KIHISTIKU (PŌHJA-EESTI TREMADOK) LITOLOOGIAST JA VANUSEST}

Põhja-Eestis leviva varangu kihistiku (joon. 1) ülemises osas esinevad peamiselt tihedad rohekashallid kiltjad savid (hüdrovilku $85-95 \%$, kloriiti $5-15 \%$ ), alumises osas aga kvartsglaukoniit-aleuroliidid, miktiidid, liivakivid ja savid (joon. 4). Kihistiku alumine ja ülemine piir kujutab enesest uhtepinda (joon. 2, 3 ja 5). Uhtepindu esineb ka kihistikus.

Konodontide liigiline koostis varangu kihistikus erineb tunduvalt latorpi lademe konodontide liigilisest koostisest Eestis, kuid on peaaegu samasugune Rootsi tseratopüüge lademe omaga (tab.). See lubab oletada, et varangu kihistik Pōhja-Eestis vastab kas kogu tseratopüüge lademele või ainult osale temast. Konodontide liikide jaotumise järgi vổib (joon. 6) läbilōikes et istada kaks osa (vööd?), mis langevad kokku litoloogiliste tunnuste järgi eristatud kihistiku osadega.

\section{VIIVE VIIRA, E. KIVIMÄGI, A. LOOG}

\section{ON THE LITHOLOGY AND AGE OF THE VARANGU MEMBER (TREMADOCIAN, NORTH-ESTONIA)}

The Varangu Member of Northern Estonia (Fig. 1) consists in its lower part of quartz-glauconite siltstones, mictites, sandstones and clays, and in the upper part mainly of compact, greenish-gray fissile clays (hydromica - 85-95 per cent, chlorite 5-15 per cent (Fig. 4). The boundaries of the member are marked by discontinuity surfaces (Figs 2, 3 and 5). They are to be found inside the member as well.

The conodonts of the Varangu Member considerably differ from those of the Estonian Latorp Stage, but are almost identical with the conodonts of the Swedish Ceratopyge Beds (Table). This allows us to assume that the Varangu Member may be correlated either entirely or partially with the Ceratopyge Beds. According to the distribution of characteristic conodont species (Fig. 6), in the Varangu Member two zones may be distinguished, which correspond to the two parts of the member defined lithologically. 